\title{
A comparative view to heavy metal pollution in soil and rainwater in Çanakkale, Turkey
}

\author{
Sibel Mentese ${ }^{1 *}$, Ozlem Tonguc Yayintas ${ }^{2}$, Batuhan Bas ${ }^{1}$, \\ Latife Ceyda İrkin ${ }^{6}{ }^{3}$ and Selehattin Yilmaz ${ }^{4}$
}

\author{
${ }^{I}$ Çanakkale Onsekiz Mart University, Faculty of Engineering, Department of Environmental \\ Engineering, Çanakkale, Türkiye \\ ${ }^{2}$ Çanakkale Onsekiz Mart University, Faculty of Medicine, Department of Medical Biology, \\ Çanakkale, Türkiye \\ ${ }^{3}$ Çanakkale Onsekiz Mart University, Faculty of Applied Sciences, Department of Fisheries Technology, \\ Çanakkale, Türkiye \\ ${ }^{4}$ Çanakkale Onsekiz Mart University, Faculty of Science and Arts, Department of Chemistry, \\ Çanakkale, Türkiye
}

(Received September 22, 2020; Revised November 30, 2020; Accepted December 12, 2020)

\begin{abstract}
On Earth, atmosphere interact with crust and thus simultaneously monitoring of environmental pollution in both parts of the environment is important. Soil and rainwater samples were taken in different parts of Çanakkale, Turkey, in two seasons. Study sites laid along with the prevailing wind direction (from NE to SW) as wind has the potential to distribute pollutants emitted into the air throughout its path. The concentrations of selected elements were determined by Inductively Coupled Plasma-Mass Spectrometry (ICP-MS). Also, physical parameters such as $\mathrm{pH}$, temperature, electrical conductivity of the rainwater and temperature and $\mathrm{pH}$ value of the soil samples were measured together with the meteorological parameters. Seasonal differences for the selected elements were insignificant in the soil samples $(p>0.05)$, while some elements showed seasonal variations in the rainwater samples $(p<0.05)$. The highest average heavy metal levels were found for $\mathrm{Zn}>\mathrm{Pb}>\mathrm{Mn}>\mathrm{Cu}>\mathrm{Cd}>\mathrm{Ni}>\mathrm{Cr}$ in the rainwater samples and $\mathrm{Mn}>\mathrm{Zn}>\mathrm{Cu}>\mathrm{Pb}>\mathrm{Cr}>\mathrm{Ni}>\mathrm{Co}$ in the soil samples, respectively. The highest enrichments were found for $\mathrm{Pb}$ in the rainwater and As in the soil samples. Elevated As levels occurred in the samples can pose a great risk for public health and agriculture.
\end{abstract}

Keywords: Atmospheric pollution; Çanakkale; ICP-MS; meteorological parameters; rainwater; soil pollution. @ 2021 ACG Publications. All rights reserved.

\section{Introduction}

On Earth, atmosphere interact with crust and thus monitoring the environmental pollution simultaneously in both parts of the environment is important. Presence of impurities in the atmosphere in quantity and time that harming health, living things, and ecological balance is called air pollution, originated both from natural and human-made sources [1]. Air pollutants can be found in the form of soot,

\footnotetext{
* Corresponding author E-Mail: sibelmentese@gmail.com
} 
smoke, dust, gas, steam, and aerosols in the air which alter the natural composition of the air [1]. Air pollution has reached serious levels in our country and the world mostly due to rapid industrialization and urban sprawl. The increase in the number of vehicles and the need for heating and the failure to take adequate and necessary measures to prevent air pollution from the industrial activities expand the dimensions of air pollution [2]. Heavy metal composition in the air is linked with not only atmospheric pollution, but also soil and water pollution, since molecular weights of typical heavy metals found in the air are heavier than other gaseous pollutants and they adsorb on the particles while settling on any surface due to gravity [3]. Also, meteorological parameters play a role on the distribution of heavy metals in the air.

In general, soil constitutes the largest receiving environment in the ecosystem that exposed to all metal contamination. Also, in aqueous systems such as rivers, lakes, and swamps, heavy metals accumulate in sediments. Therefore, heavy metals found in drinking water and other natural water resources [4]. For this reason, many studies are focused on the analysis of environmental samples such as water, soil, and sediment [5]. Heavy metals are found in the soil discharged from different sources such as traffic, industrial activities, ore-mine processing facilities, excessive fertilizer application, waste water and waste sludge applications [6-8], which pose a risk for arable lands. Also, the total metal concentrations in the soil are directly related to the soil parent material. However, the mobility of metals spread to the environment by human origin is higher than lithospheric sources [9-11].

The aim of this study to determine the heavy metal content in the soil and rainwater samples collected from different parts of Çanakkale city.

\section{Experimental}

Soil and rainwater samples were taken from 5 different sampling locations in Çanakkale (Turkey) in November 2017 and May 2018. Rainwater samples were collected no later than 6 weeks after the first placement of the samplers at the sampling sites. Time duration of the rainwater sample collection was variable due to local variability in rain events and the amount of rainwater accumulated in the samplers. Duplicate rainwater samplers were placed alongside and triple composite soil samples were taken at the sampling sites. The analyses of the soil and rainwater samples were performed immediately after the collection from the study sites. Meteorological parameters were obtained from Turkish Meteorological Institute throughout the study period. Also, as rain event has an importance on rainwater sample collection, weather forecasts and satellite observations (NOAA) were followed over the sampling periods. Furthermore, atmospheric temperature and relative humidity $(\mathrm{RH})$ values were measured at the time of sampling by a real-time instrument (Testo 435-2).

\subsection{Study Sites}

The sampling sites were selected through the major wind blowing direction and estimated preliminarily on the city map. Long-term meteorological records indicate that the prevailing wind direction has been from NE to SW and secondarily from opposite direction which was from SW to NE directions [2,12-13]. All sampling sites were chosen at non-residential and rural areas to minimize the contribution of any potential anthropogenic sources such as domestic, traffic, and industrial processes. Final locations of the sampling sites were then determined after the preliminary observations at the field that had the best representation of the study aim. Rainfall forecasts and real-time rain occurrences over the region were followed to determine the sampling period. Çanakkale city is laid on both the European and Asian continents with the transient climatic characteristics of the Mediterranean and Black Sea regions [14]. The sampling points of this study were located at Ayvacik, Bayramic, Çan, Etili, and Karabiga regions of the city (see Figure 1). In terms of distance of the sampling sites from the potential environmental pollution sources, Karabiga and Çan are very close to coal-fired power plants, while Ayvacik and Bayramiç are located in Mount Ida forests. Also, active granite/stone mine quarries are available near Karabiga. Open coal mines and a ceramic factory facilitate in Çan center. Etili is located between Çan and Çanakkale city center. Sampling sites are not close to residential areas nor potential traffic sources. 


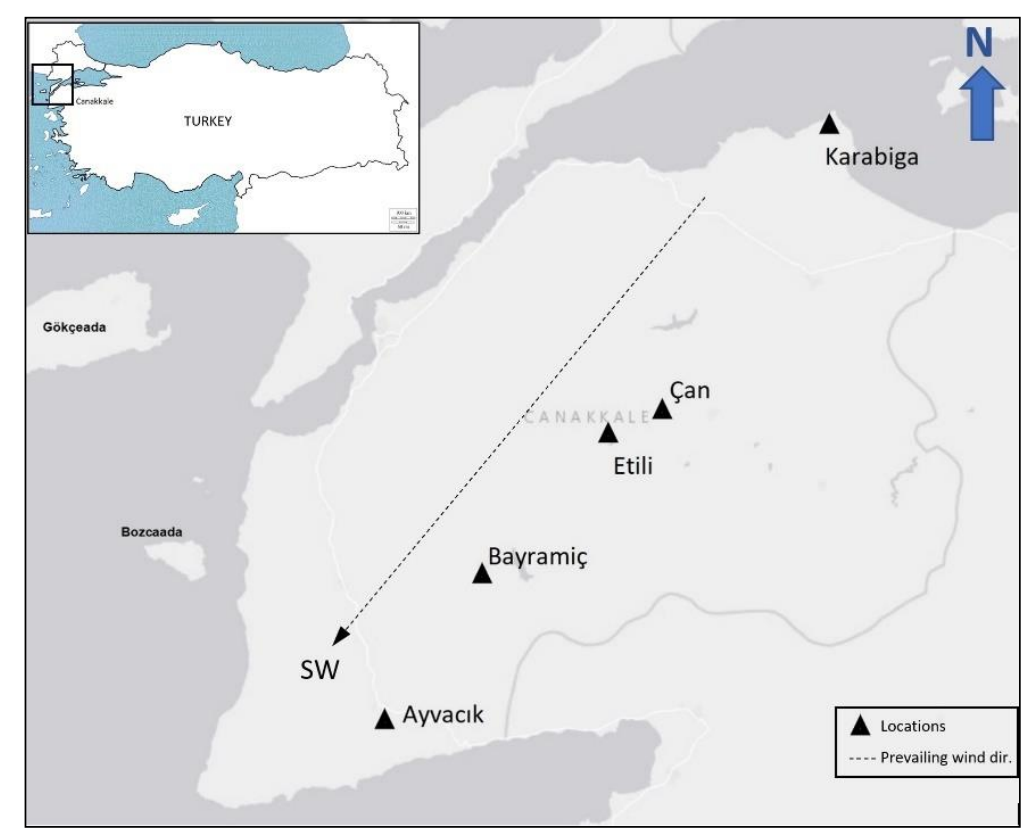

Figure 1. Locations of the study sites (Ayvacik, Bayramic, Çan, Etili, and Karabiga)

\subsection{Sampling and Analysis of the Rainwater Samples}

Rainwater samplers [15] were placed in the sampling locations in two seasons. As a rainwater collection system, two-step collection vessels made of polyethylene (PE) were placed on top of a rigid wooden stick at $1.50 \mathrm{~m}$ above the ground. A glass-fiber filter $(2.0 \mu \mathrm{m}$ pore size and $47 \mathrm{~mm}$ diameter: Merck Millipore Inc., Ireland) on a PE filter holder was bonded between two funnel-vessels. Rainfall initially dropped into the first funnel through the holes on the first funnel (at the top). Particles accumulated on the filter and the remaining rain drops were accumulated in the second vessel (i.e. collection funnel), which was then analyzed to determine the elemental content. Duplicate rainwater samplers were placed at each sampling point not to lose rainwater sample from the external factors. Containers filled with rainwater $(\geq 50 \mathrm{ml})$ were taken from the sampling points no later than 6 weeks after the placement of the rainwater samplers, depending on the accumulated amount of the rainfall in the meantime. Rainwater samples in the collection vessel were analyzed by ICP-MS. Also, temperature $\left({ }^{\circ} \mathrm{C}\right)$, $\mathrm{pH}$, electrical conductivity $(\mathrm{EC} ; \mu \mathrm{s} / \mathrm{cm})$, etc. of the rainwater samples were measured by a multi-parameter probe (WTW Multi 3510 IDS multiparameter). The rainwater samples were then sent to an accredited laboratory (ACME Lab, Canada) to be analyzed for the elemental content by Inductively Coupled PlasmaMass Spectrometry (ICP-MS). To determine trace to ultra-trace concentrations of the elements in the rainwater, the samples were analyzed directly by an ICP-MS and higher concentrations were confirmed by Inductively Coupled Plasma Optical Emission spectroscopy (ICP-OES).

\subsection{Sampling and Analysis of Soil Samples}

Soil samples were taken from a 5-15 cm deep hole dug in the form of a "V" at the sampling points in two seasons. A real-time instrument (Floureon, 4 in 1 soil survey instrument) was used to record temperature and $\mathrm{pH}$ value of the soil at the time of sampling. The soil samples were taken as a mixture of triple soil samples to represent each sample sites. The soil samples were mixed with approximately 0.5 $\mathrm{kg}$ of sample taken from different points of the same sampling sites [16]. Soil samples were stored in a cool and clean environment until the analyses. Coarse matters such as leaves and rocks were taken out from the soil mixture. Humidity content of the soil was determined by the gravitational method [17]. It indicates the mass difference between the soil dried at $105^{\circ} \mathrm{C}$ for overnight and wet, raw soil. The size of the soil in the dried soil samples was decreased to several nanometers using the corresponding sieves for 
further analysis. Afterwards, soil samples were analyzed in an accredited laboratory (ACME Lab, Canada) to determine the composition of the selected elements. Briefly, the soil samples were digested with a modified Aqua Regia solution concentrated with $\mathrm{HCl}, \mathrm{HNO}_{3}$ and deionized (DI) water in a heating block or hot water bath for one hour. The adjusted sample volume diluted with $\mathrm{HCl}$ and then analyzed by the ICP-MS.

\subsection{Data Evaluation}

SPSS 19.0 software was utilized to perform statistical analyses. To find associations between the parameters, simple regression models and Spearman rank correlation tests were used. ANOVA test was applied to the data set to determine the seasonal variation of the measured elemental levels in the soil and rainwater samples. Values with $p<0.05$ were considered statistically significant for all applied tests.

The enrichment factor (EF) of the selected elements in the samples (soil or rainwater) was computed with reference to aluminum, as a conservative crustal element used in soil pollution studies [1819], according to Equation (1):

$$
\mathrm{EF}=\left(\mathrm{C}_{\text {element }} / \mathrm{C}_{\text {ref }}\right)_{\text {sample }} /\left(\mathrm{C}_{\text {element }} / \mathrm{C}_{\text {ref }}\right)_{\text {earth crust }}
$$

where $\mathrm{C}_{\text {element }}$ is the concentration of the metal and $\mathrm{C}_{\text {ref }}$ is the concentration of the reference element in the sample (soil or rainwater) earth's crust [20].

\section{Results and discussion}

\subsection{Meteorological Parameters and Physical Parameters of the Samples}

Atmospheric temperature and $\mathrm{RH}$ values at the time of samplings were over $9{ }^{\circ} \mathrm{C}$ and $63-75 \%$ in the fall and over $19{ }^{\circ} \mathrm{C}$ and $39-56 \%$ in the spring, respectively. Strong northern winds and rarely southern winds were the most frequent winds. The minimum and maximum levels of the rain amount occurred in the spring sampling and in the fall, respectively. Soil $\mathrm{pH}$ was around $6.5-7.0$ and the soil temperature was over $6{ }^{\circ} \mathrm{C}$ in the fall and over $11^{\circ} \mathrm{C}$ in the spring. Humidity content of the soil samples was lower in the spring season than in the fall season due to increased levels of soil temperature and a relatively dry season, observed before the spring sampling campaign.

The lowest $\mathrm{pH}$ values (>3.3) in the rainwater samples were measured in the fall season for all sampling sites. Overall, the lowest $\mathrm{pH}$ values were recorded in Etili, compared to other locations. Typical rainwater $\mathrm{pH}$ is around 5.4 - 5.6 due to the weak acidic effect of $\mathrm{CO}_{2}$ in the air [1] and thus $\mathrm{pH}$ values that lower than 5.4 - 5.6 indicate the acidic rain. Rainwater $\mathrm{pH}$ values were lower than 5.6 at all sampling points, except for Karabiga as a result of alkalinity alteration by $\mathrm{Ca}$ or $\mathrm{Mg}$ ions, as these elements were available there (e.g., active limestone mines). Therefore, the alkalinity level of the rainwater samples might have increased by the aerosols accumulated in the air, which was in accordance with studies conducted in Mugla, Turkey [21] and Iran [22]. Earlier researches carried out in the Aegean or Marmara regions of Turkey also indicated the less acidic rainwater observations with the $\mathrm{pH}$ of as high as 7.72 [21,23-30]. Electrical conductivity of the rainwater samples (65 and $436 \mu \mathrm{S} / \mathrm{cm})$ were in the acceptable range of our national tap water standard, TS 266 [31]. The EC value of the rainwater was likely to increase with cations dissolved in the rainwater. Compared to EC values observed in the rainwater samples in this study, higher EC levels were measured in ground water samples collected in Çanakkale region [32-35].

\subsection{Spatial and Seasonal Variations of Minerals and Heavy Metals in the Samples}

Minerals and heavy metals in the soil and rainwater samples are presented according to spatial and seasonal variations. Major elements such as $\mathrm{Al}, \mathrm{Ca}, \mathrm{Fe}$, and $\mathrm{Mg}$ are assumed to be vital for the earth's crust [36]. Thus, their levels are mostly not related to pollution, depending on the corresponding enrichment factor $(\mathrm{EF})$ in the soil or air. As general, the anthropogenic heavy metals selected in this study (e.g., $\mathrm{As}, \mathrm{Cd}, \mathrm{Co}, \mathrm{Cr}, \mathrm{Cu}, \mathrm{Mn}, \mathrm{Ni}, \mathrm{Pb}, \mathrm{V}, \mathrm{Zn}$, and $\mathrm{Hg}$ ) were found above the method detection limits 
(MDL). Some elements (Ag, Au, and As) were linked with volcanic activity, geo-thermal zones, and/or radioactivity ( $\mathrm{Th}$ and $\mathrm{U}$ ). Therefore, those elements are given separately from the indicator elements of the anthropogenic pollution.

\subsubsection{Mineral and Heavy Metal Levels in the Soil Samples}

The concentrations of the measured elements in the soil samples taken from the sampling points in the fall and spring seasons are given in Table 1. No statistically significant difference was found in terms of seasonality for the selected elemental content of the soil samples taken from each study site $(p>0.05)$.

Table 1. Elemental content of the dry-soil samples taken from the study points.

\begin{tabular}{cccccc}
\hline Element & Unit & MDL & Fall & Spring & $\begin{array}{c}\text { Background } \\
\text { concentrations }\end{array}$ \\
\hline \multicolumn{2}{c}{ Major elements } & & & & \\
$\mathrm{Al}$ & $\%$ & 0.01 & $2.1 \pm 1.13$ & $1.57 \pm 0.48$ & $7.1^{\mathrm{a}}, 7.96^{\mathrm{b}}$ \\
$\mathrm{Ca}$ & $\%$ & 0.01 & $0.6 \pm 0.37$ & $0.65 \pm 0.34$ & $3.85^{\mathrm{b}}$ \\
& & & & & \\
$\mathrm{Fe}$ & $\%$ & 0.01 & $3.14 \pm 1.11$ & $2.81 \pm 0.84$ & $4^{\mathrm{a}}, 4.32^{\mathrm{b}}$ \\
$\mathrm{Mg}$ & $\%$ & 0.01 & $0.35 \pm 0.20$ & $0.34 \pm 0.11$ & $2.20^{\mathrm{b}}$ \\
$\mathrm{K}$ & $\%$ & 0.01 & $0.29 \pm 0.10$ & $0.17 \pm 0.05$ & $2.14^{\mathrm{b}}$ \\
$\mathrm{Na}$ & $\%$ & 0.001 & $0.02 \pm 0.03$ & $0.02 \pm 0.01$ & $2.36^{\mathrm{b}}$ \\
$\mathrm{P}$ & $\%$ & 0.001 & $0.06 \pm 0.01$ & $0.05 \pm 0.02$ & $0.0757^{\mathrm{b}}$ \\
\hline Anthropogenic pollution & indicators & & \\
$\mathrm{Cd}$ & $\mathrm{mg} / \mathrm{kg}$ & 0.01 & $0.5 \pm 0.5$ & $0.3 \pm 0.3$ & $0.35^{\mathrm{a}}, 0.10^{\mathrm{b}}$ \\
$\mathrm{Co}$ & $\mathrm{mg} / \mathrm{kg}$ & 0.1 & $19.3 \pm 6.9$ & $14.8 \pm 6.6$ & $8^{\mathrm{a}}, 24^{\mathrm{b}}$ \\
$\mathrm{Cr}$ & $\mathrm{mg} / \mathrm{kg}$ & 0.5 & $39.7 \pm 20.2$ & $32.9 \pm 31.8$ & $70^{\mathrm{a}}, 126^{\mathrm{b}}$ \\
$\mathrm{Cu}$ & $\mathrm{mg} / \mathrm{kg}$ & 0.01 & $39.7 \pm 19.1$ & $43.2 \pm 34.0$ & $30^{\mathrm{a}}, 25^{\mathrm{b}}$ \\
$\mathrm{Hg}$ & $\mathrm{mg} / \mathrm{kg}$ & 0.005 & $0.13 \pm 0.12$ & $0.07 \pm 0.05$ & $0.06^{\mathrm{a}}, 0.04^{\mathrm{b}}$ \\
$\mathrm{Mn}$ & $\mathrm{mg} / \mathrm{kg}$ & 1 & $1222 \pm 395$ & $927 \pm 255$ & $1000^{\mathrm{a}}, 716^{\mathrm{b}}$ \\
$\mathrm{Mo}$ & $\mathrm{mg} / \mathrm{kg}$ & 0.01 & $1.3 \pm 0.7$ & $4.0 \pm 7.0$ & $1.2^{\mathrm{a}}, 1.1^{\mathrm{b}}$ \\
$\mathrm{Ni}$ & $\mathrm{mg} / \mathrm{kg}$ & 0.1 & $36.9 \pm 21.1$ & $29.3 \pm 24.0$ & $50^{\mathrm{a}}$ \\
$\mathrm{Pb}$ & $\mathrm{mg} / \mathrm{kg}$ & 0.01 & $43.7 \pm 13.0$ & $30.7 \pm 8.4$ & $35^{\mathrm{a}}, 14.8^{\mathrm{b}}$ \\
$\mathrm{V}$ & $\mathrm{mg} / \mathrm{kg}$ & 1 & $66.3 \pm 29.7$ & $61.4 \pm 22.5$ & $90^{\mathrm{a}}, 98^{\mathrm{b}}$ \\
$\mathrm{Zn}$ & $\mathrm{mg} / \mathrm{kg}$ & 0.1 & $68.6 \pm 22.0$ & $61.3 \pm 16.3$ & $90^{\mathrm{a}}, 65^{\mathrm{b}}$ \\
\hline Volcanic/Geo-thermal/Radioactive elements & & \\
$\mathrm{Ag}$ & $\mu \mathrm{g} / \mathrm{kg}$ & 2 & $108.6 \pm 85.0$ & $60.4 \pm 56.7$ & $50^{\mathrm{a}}, 70^{\mathrm{b}}$ \\
$\mathrm{As}$ & $\mathrm{mg} / \mathrm{kg}$ & 0.1 & $25.5 \pm 16.6$ & $18.5 \pm 10.2$ & $6^{\mathrm{a}}, 1.7^{\mathrm{b}}$ \\
$\mathrm{Au}$ & $\mu \mathrm{g} / \mathrm{kg}$ & 0.2 & $4.5 \pm 5.4$ & $12.5 \pm 26.8$ & $2.5^{\mathrm{b}}$ \\
$\mathrm{Th}$ & $\mathrm{mg} / \mathrm{kg}$ & 0.1 & $7.6 \pm 5.1$ & $6.2 \pm 3.4$ & $8.5^{\mathrm{b}}$ \\
$\mathrm{U}$ & $\mathrm{mg} / \mathrm{kg}$ & 0.1 & $1.7 \pm 1.2$ & $1.6 \pm 1.2$ & $2^{\mathrm{a}}, 1.7^{\mathrm{b}}$ \\
\hline
\end{tabular}

${ }^{\mathrm{a}}$ [37]; ${ }^{\mathrm{b}}$ [20]; MDL: method detection limit; fall and spring season concentrations are shown as average \pm standard deviation.

Elemental content of the soil is compared with background levels of earth crust given by Bowen [37] and Wedepohl [20]. Major components of the soil had concentration order as follows: $\mathrm{Fe}>\mathrm{A} 1>\mathrm{Ca}$ $>\mathrm{Mg}>\mathrm{K}>\mathrm{P}>\mathrm{Na}$, in descending order. Merely proportion of $\mathrm{P}$ in the soil was slightly higher than 
background earth's crust level. Concentration order of the anthropogenic pollution indicators was $\mathrm{Mn}>$ $\mathrm{Zn}>\mathrm{V}>\mathrm{Cu}>\mathrm{Pb}>\mathrm{Cr}>\mathrm{Ni}>\mathrm{Co}$, in descending order. Mineral and heavy metal concentrations in the soil samples were compared with Turkish Soil Pollution Control Regulation [38]. With this regard, measured elemental concentrations in the soil samples exceeded merely As limit value $(0.4 \mathrm{mg} / \mathrm{kg}$ by oral intake or skin contact) at all sampling sites and the Co limit value ( $23 \mathrm{mg} / \mathrm{kg}$ by oral intake or skin contact) at Bayramiç and Etili. The amount of As in the soil samples was quite high compared to the limit values. A study conducted around Ayvacik found very high As levels in the groundwater and they showed that the source of As was linked with alteration zones in the volcanic rocks [33]. Even though relatively low levels of $\mathrm{Cu}, \mathrm{Pb}$, and $\mathrm{Zn}$ were observed here, $\mathrm{Cu}-\mathrm{Pb}-\mathrm{Zn}$ mines are present particularly around Çan and Etili, while $\mathrm{Mn}, \mathrm{Au}$, and $\mathrm{Ag}$ are also rarely found close to Etili and between Ayvacik and Bayramiç regions, according to the national mapping study for Çanakkale [39]. Average levels of Ag, As, and Au were markedly higher than the background levels of earth's crust. Specifically, Au availability close to the Mount Ida region (covers Ayvacik, Bayramiç, and Edremit region) is of local concern, since gold has already attracted several international gold exploration companies here. As radioactive elements, average levels of Th and $\mathrm{U}$ were slightly higher than the background levels.

Table 2 shows the comparison of average elemental levels of the soil samples collected in the fall and spring seasons at all study sites with the literature: Cd levels were lower than those measured in Pakistan [40], Mexico City [41], and Poland [42]; Cr levels were lower than those measured at India [43]; $\mathrm{Cu}$ levels were higher than Mardin [44], Hatay [45], Pakistan [40], Nigeria [46], and Tibet [47]; Ni levels were higher than Hatay [45], Nigeria [46], Pakistan [40], Tibet [47], Germany and Poland [42]; Pb levels were higher than Tibet [47], Pakistan [40], Mardin [44], and Hatay [45]; and $\mathrm{Zn}$ levels were higher than Hatay [45], Nigeria [46], and Pakistan [40].

EF values are categorized in five enrichment classes to indicate trace elemental pollution in the soil: $i) \mathrm{EF}<2$ : minimal enrichment, ii) $2<\mathrm{EF}<5$ : moderate enrichment, iii) $5<\mathrm{EF}<20$ : significant enrichment, iv) $20<\mathrm{EF}<40$ : very high enrichment, and v) $\mathrm{EF}>40$ shows extremely high enrichment [51-52]. Average $\mathrm{EF}$ values of $\mathrm{As}, \mathrm{Cd}, \mathrm{Pb}, \mathrm{Hg}, \mathrm{Mn}, \mathrm{Cu}, \mathrm{Ni}$, and $\mathrm{Zn}$ in the soil samples showed variations among the sampling sites in terms of enrichment classes over the study period, as given in Figure 2 . The fact that $\mathrm{EF}$ values for $\mathrm{Ca}, \mathrm{Cr}$, and $\mathrm{Mg}$ were in the first enrichment class, no anthropogenic pollution source exists in the study sites in terms of the major components of the soil. Several studies carried out close to Çan and Etili showed the contribution of coal-fired power plants to the $\mathrm{As}, \mathrm{Cd}, \mathrm{Cr}, \mathrm{Pb}, \mathrm{Zn}$, and Se contents of water and fly ash samples collected around the region [7,32]. Once the Cd level in Bayramiç in the fourth enrichment class, indicating very high enrichment, was excluded, $\mathrm{Cd}, \mathrm{Pb}, \mathrm{Hg}, \mathrm{Mn}$, and $\mathrm{Cu}$ levels were found to be in the second and third enrichment classes, showing moderate to significant enrichment of those heavy metals in the soil samples. The potential sources of those heavy metals were explained as the geomorphological characteristics of the region, presence of coals and other mines, and usage of local coal in the coal-fired power plants located in Karabiga and between Çan and Etili $[7,32,33,53,54]$. Parallel to that, soil samples collected along the prevailing wind directions to determine the effect of Çayirhan power plant (in Ankara, Turkey) emissions on the region found higher heavy metal levels along the prevailing wind direction, compared to the opposite direction of the prevailing wind [55]. The highest levels of $\mathrm{Cr}, \mathrm{Cu}, \mathrm{Ni}$, and $\mathrm{Pb}$ that given in Table 2 were observed in the soil collected from Kolaghat, India [43], where thermal power plants were shown the main source of heavy metal pollution in the soil. Another study conducted in the industrial region of Samsun-Tekkeköy, Turkey showed that soil samples that were close to the industrial facilities exceeded the critical levels for $\mathrm{As}, \mathrm{Cr}, \mathrm{Cu}, \mathrm{Ni}$, and $\mathrm{Zn}[56]$. The major sources of heavy metal pollution in surface soil around Gebze industrial area, Turkey were shown as hazardous wastes distributed from the industrial plants through rain or wind and traffic [57]. In another study carried out in multiple points of İstanbul, Tukey, proximity to highways showed higher levels of heavy metals than the secondary roads [50]. In an extensive study conducted in multiple cities of different Asian and European countries indicated the remarkable contribution of anthropogenic heavy metals such as $\mathrm{Cu}, \mathrm{Cd}, \mathrm{Zn}$, and $\mathrm{Pb}$ in the roadside soil contents [42]. All sampling locations of our present study were far from the traffic sources. In some studies, traffic appeared to be the major anthropogenic source of the heavy metals (e.g., [3,6,58]). Unlike those studies, traffic was not considered as a major anthropogenic source in this study. Instead, mining activities and coal-fired power plants were the major anthropogenic sources, in addition to the potential contribution of natural rock characteristics 
of the soil on enrichment of some heavy metals such as As. Relatively high As levels were noted in the previous studies conducted in Çanakkale $[7,32,33,53,54]$.

Table 2. Comparison of levels (mg/kg-dry soil) of the selected anthropogenic heavy metals observed in the soils collected from different countries.

\begin{tabular}{|c|c|c|c|c|c|c|}
\hline Country (city) & $\mathrm{Cd}$ & $\mathrm{Cr}$ & $\mathrm{Cu}$ & $\mathrm{Ni}$ & $\mathrm{Pb}$ & $\mathrm{Zn}$ \\
\hline Hong Kong [6] & $0.02-5.9$ & - & $5.1-190$ & - & $5.3-404$ & $38.7-435$ \\
\hline Tibet [47] & $0.05-0.4$ & $35-58$ & $11.3-20.5$ & $10-24.8$ & $16.6-42$ & $28-77.3$ \\
\hline Pakistan [40] & 0.8 & - & 13.0 & 8.8 & 36.5 & 56.7 \\
\hline India (Kolaghat) [43] & - & 101.4 & 70.4 & 52.3 & 26.6 & 148.6 \\
\hline Nigeria [46] & $0.4-1.1$ & - & 27.7 & $7-12.3$ & $71-113$ & $44.7-67.9$ \\
\hline Mexico (Mexico City) [41] & 1.7 & - & 101.5 & - & 921 & 666.5 \\
\hline Dubai $[48]$ & $0.17-1.0$ & - & $15.5-65.9$ & $13.3-98$ & $260-278$ & $72.4-170.3$ \\
\hline Poland (Zabrze) [42] & 5.2 & 28 & 70 & 23 & 210 & 870 \\
\hline Germany (Übingen) [42] & 0.3 & 13 & 80 & 22 & 56 & 200 \\
\hline Italy [49] & - & $1.7-73$ & $6.2-286$ & - & $4-3420$ & $30-2550$ \\
\hline Turkey (İstanbul) [50] & - & - & $\begin{array}{l}68.7^{\mathrm{b}} \\
23.4^{\mathrm{c}}\end{array}$ & - & $\begin{array}{l}191^{b} \\
29.7^{c}\end{array}$ & $\begin{array}{l}255^{\mathrm{b}} \\
96.6^{\mathrm{c}}\end{array}$ \\
\hline Turkey (Mardin) [44] & $0.26-0.4$ & $17-28$ & $9.9-14.2$ & $27-42$ & $0.6-2.2$ & - \\
\hline Turkey (Konya) [51] & - & - & 144.4 & 1832 & 60 & 225.9 \\
\hline Turkey (Hatay) [45] & $0-0.3$ & $0-0.1$ & $0.4-5.4$ & $0.4-4$ & $0.1-0.8$ & $0-4.3$ \\
\hline Turkey $(\text { Çanakkale })^{a}$ & $\begin{array}{c}0.3 \\
(0.1-1.4) \\
\end{array}$ & $\begin{array}{c}36.3 \\
(6-84) \\
\end{array}$ & $\begin{array}{c}41.5 \\
(14-97) \\
\end{array}$ & $\begin{array}{c}33.1 \\
(7.6-60.2) \\
\end{array}$ & $\begin{array}{c}37.2 \\
(18-57) \\
\end{array}$ & $\begin{array}{c}64.9 \\
(45-103) \\
\end{array}$ \\
\hline
\end{tabular}

${ }^{\mathrm{a}}$ This study; min - max (avg.); ${ }^{\mathrm{b}}$ surface soil from highway, ${ }^{\mathrm{c}}$ surface soil from secondary roads.

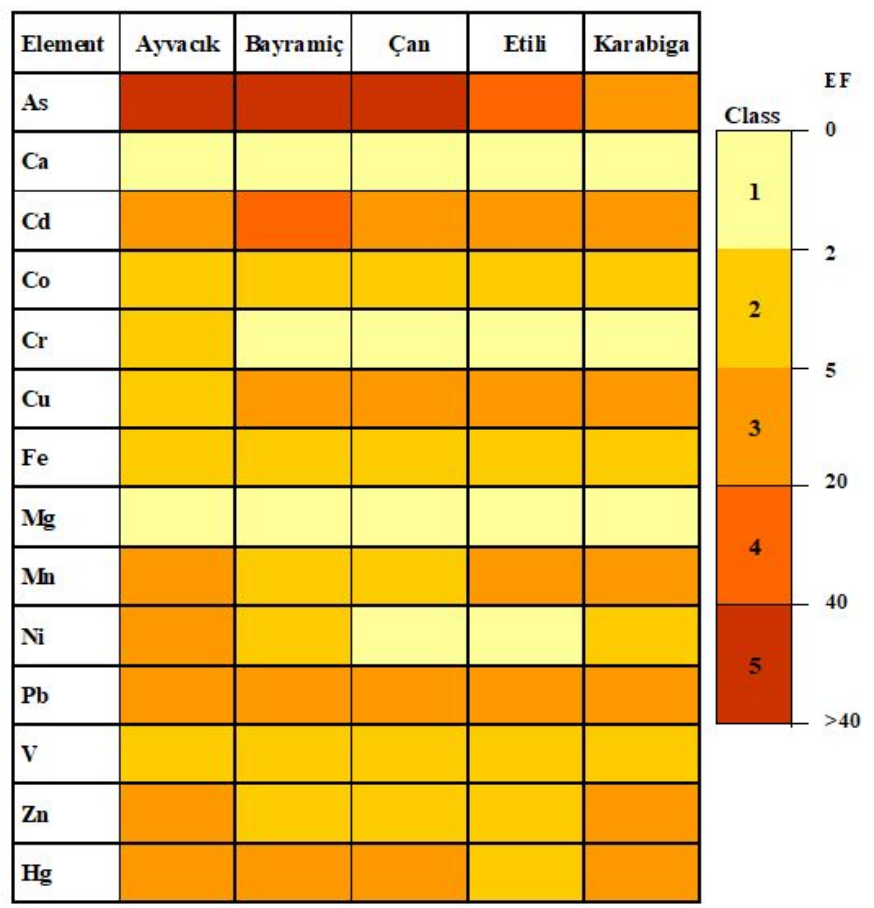

Figure 2. Heat map for enrichment factor $\left(\mathrm{EF}_{\text {soil }}\right)$ of the selected elements in soil over the study period at the study sites 


\subsubsection{Mineral and Heavy Metal Levels in the Rainwater Samples}

The concentrations of the selected elements in the rainwater samples collected at the sampling points in the fall and spring seasons are given in Table 3. Statistically significant differences were found between the rainwater samples taken in the fall and spring $(p<0.05)$. Average concentration order in rainwater samples was $\mathrm{Zn}>\mathrm{Pb}>\mathrm{Al}>\mathrm{Fe}>\mathrm{Mn}>\mathrm{Cu}>\mathrm{Cd}>\mathrm{Ni}>\mathrm{Cr}$, in descending order. Average concentrations of $\mathrm{Cd}, \mathrm{Cr}, \mathrm{Cu}, \mathrm{Mn}, \mathrm{Ni}, \mathrm{Pb}, \mathrm{Se}, \mathrm{V}$, and $\mathrm{Zn}$ were higher than those in the background freshwater composition [37].

Table 3. Elemental content of the rainwater samples taken from the study points

\begin{tabular}{cccccc}
\hline Element & Unit & MDL & Fall & Spring & $\begin{array}{c}\text { Background } \\
\text { concentrations } \\
\text { [37] }\end{array}$ \\
\hline \multicolumn{2}{c}{ Major elements } \\
$\mathrm{Ca}$ & $\mathrm{mg} / \mathrm{L}$ & 0.05 & $2.9 \pm 1.4$ & $9.6 \pm 6.0$ & - \\
$\mathrm{Mg}$ & $\mathrm{mg} / \mathrm{L}$ & 0.05 & $0.5 \pm 0.3$ & $1.7 \pm 1.3$ & - \\
$\mathrm{Na}$ & $\mathrm{mg} / \mathrm{L}$ & 0.05 & $3.5 \pm 0.9$ & $5.4 \pm 2.6$ & - \\
$\mathrm{K}$ & $\mathrm{mg} / \mathrm{L}$ & 0.05 & $0.7 \pm 0.5$ & $10.2 \pm 9.6$ & - \\
\hline
\end{tabular}

\begin{tabular}{cccccc}
\hline \multicolumn{5}{c}{ Anthropogenic pollution indicators } & \\
$\mathrm{Al}$ & $\mu \mathrm{g} / \mathrm{L}$ & 1 & $30.4 \pm 28.4$ & $33.2 \pm 36.6$ & 300 \\
$\mathrm{Cd}$ & $\mu \mathrm{g} / \mathrm{L}$ & 0.05 & $4.6 \pm 3.7$ & $6.7 \pm 5.5$ & 0.1 \\
$\mathrm{Co}$ & $\mu \mathrm{g} / \mathrm{L}$ & 0.02 & $0.1 \pm 0.04$ & $0.3 \pm 0.2$ & 0.2 \\
$\mathrm{Cr}$ & $\mu \mathrm{g} / \mathrm{L}$ & 0.5 & $0.5 \pm 0.3$ & $2.3 \pm 1.6$ & 1 \\
$\mathrm{Cu}$ & $\mu \mathrm{g} / \mathrm{L}$ & 0.1 & $7.1 \pm 4.0$ & $9.1 \pm 7.6$ & 3 \\
$\mathrm{Fe}$ & $\mu \mathrm{g} / \mathrm{L}$ & 10 & $35.6 \pm 31.8$ & $21.2 \pm 16.7$ & 8 \\
$\mathrm{Mn}$ & $\mu \mathrm{g} / \mathrm{L}$ & 0.05 & $11.0 \pm 5.0$ & $39.3 \pm 19.3$ & 0.5 \\
$\mathrm{Mo}$ & $\mu \mathrm{g} / \mathrm{L}$ & 0.1 & $<0.1$ & $0.3 \pm 0.3$ & 0.5 \\
$\mathrm{Ni}$ & $\mu \mathrm{g} / \mathrm{L}$ & 0.2 & $1.3 \pm 0.6$ & $5.9 \pm 4.0$ & - \\
$\mathrm{P}$ & $\mu \mathrm{g} / \mathrm{L}$ & 10 & $87.6 \pm 79.4$ & $3584 \pm 7030$ & 3 \\
$\mathrm{~Pb}$ & $\mu \mathrm{g} / \mathrm{L}$ & 0.2 & $124.0 \pm 63.5$ & $12.5 \pm 14.6$ & 0.2 \\
$\mathrm{Se}$ & $\mu \mathrm{g} / \mathrm{L}$ & 0.5 & $<0.5$ & $3.0 \pm 1.6$ & - \\
$\mathrm{Si}$ & $\mu \mathrm{g} / \mathrm{L}$ & 40 & $225.6 \pm 328.5$ & $1147.2 \pm 6115.7$ & 0.5 \\
$\mathrm{~V}$ & $\mu \mathrm{g} / \mathrm{L}$ & 0.2 & $0.6 \pm 0.2$ & $1.1 \pm 0.5$ & 1.5 \\
$\mathrm{Zn}$ & $\mu \mathrm{g} / \mathrm{L}$ & 0.5 & $153.3 \pm 56.4$ & $368.0 \pm 382.6$ & 500 \\
\hline Volcanic/Geothermal/Radioactive elements & & \\
$\mathrm{Ag}$ & $\mu \mathrm{g} / \mathrm{L}$ & 0.05 & $<0.05$ & $0.6 \pm 0.6$ & 0.3 \\
$\mathrm{Au}$ & $\mu \mathrm{g} / \mathrm{L}$ & 0.05 & $<0.05$ & $0.07 \pm 0.05$ & - \\
$\mathrm{As}$ & $\mu \mathrm{g} / \mathrm{L}$ & 0.5 & $<0.5$ & $1.0 \pm 1.0$ & 0.5 \\
$\mathrm{Th}$ & $\mu \mathrm{g} / \mathrm{L}$ & 0.05 & $<0.05$ & $0.06 \pm 0.04$ & - \\
$\mathrm{U}$ & $\mu \mathrm{g} / \mathrm{L}$ & 0.02 & $<0.02$ & $<0.02$ & 0.4 \\
\hline
\end{tabular}

MDL: method detection limit; fall and spring season concentrations are shown as average \pm standard deviation.

Measured levels of the elements in this study are comparable with other studies conducted elsewhere. Except Jordan [59], Cd levels were higher than those measured in the places given in Table 4; Cr levels were lower than Singapore [60] and Russia [61]; Cu levels were lower than Giresun [62], Greece [63], and Jordan [59]; Fe levels were lower than Jordan [59] and Greece [63]; Ni levels were lower than Tibet [64] and France [65]; the highest Pb levels were observed in Çanakkale (this study); and except 
Giresun [62], Zn levels were higher than those observed elsewhere given in Table 4. In another study, elevated heavy metal levels were observed in Istanbul [30], probably due to the contribution of dense traffic and industry-related anthropogenic air pollutant emissions. Rainwater samples taken along the Giresun coastal road [62] showed higher concentrations of $\mathrm{Fe}, \mathrm{Zn}, \mathrm{Mn}, \mathrm{Cu}, \mathrm{Cr}, \mathrm{Ni}, \mathrm{As}$, and $\mathrm{Co}$, while lower concentrations occurred for $\mathrm{Pb}$ and $\mathrm{Cd}$ than those measured in this study. Also, the authors found no statistically significant difference between the stations $(p>0.05)$, whereas the seasonal difference was statistically significant. Major elements that were originated mostly from the earth's crust $[30,66]$ in the rainwater samples were $\mathrm{Ca}, \mathrm{K}, \mathrm{Na}$, and $\mathrm{Mg}$, in descending order.

Table 4. Comparison of concentrations ( $\mu \mathrm{g} / \mathrm{L}$ ) of the selected anthropogenic heavy metals observed in the rainwater samples taken from different countries

\begin{tabular}{|c|c|c|c|c|c|c|c|}
\hline Country (city) & Cd & $\mathrm{Cr}$ & $\mathbf{C u}$ & $\mathbf{F e}$ & $\mathbf{N i}$ & $\mathbf{P b}$ & $\mathbf{Z n}$ \\
\hline Mexico [66] & $0.04-4.5$ & - & - & - & $0.4-12.9$ & $0.6-9.3$ & - \\
\hline USA [70] & $1.1^{\mathrm{a}}, 0.27^{\mathrm{b}}$ & $0.52^{\mathrm{a}}, 0.98^{\mathrm{b}}$ & - & - & - & $0.33^{\mathrm{a}}, 1.16^{\mathrm{b}}$ & - \\
\hline Brazil [71] & 0.17 & - & 3.6 & - & - & 1.7 & 9.8 \\
\hline Tibet [64] & $<0.001-0.02$ & $<0.03-3.5$ & $0.05-4.2$ & $<0.6-132$ & $<0.04-4.37$ & $0.011-1.8$ & $0.33-33.4$ \\
\hline Singapore [60] & $0.05-0.4$ & $0.40-2.8$ & $0.7-34.1$ & $3.2-63.8$ & $0.8-6.5$ & $0.21-12.6$ & $0.93-11.7$ \\
\hline China [67] & 1 & - & 5 & - & - & - & 96 \\
\hline Jordan [59] & 42 & - & 40 & 21.5 & 1.75 & 51 & 32 \\
\hline Russia [61] & $0.08-3.4$ & $0.2-0.5$ & $1.3-31.6$ & - & - & $0.17-0.7$ & $21.6-113$ \\
\hline France [72] & 0.11 & - & 1.4 & - & - & 2.8 & 21.8 \\
\hline France [65] & $<0.01-0.06$ & - & - & - & $0.3-1.15$ & $0.08-0.73$ & $2.4-22.9$ \\
\hline Greece [63] & 0.06 & 1.2 & 2.9 & - & - & 3.3 & 39 \\
\hline Greece [73] & 0.2 & - & 15.4 & 4.4 & 4.14 & 0.88 & 33.5 \\
\hline $\begin{array}{l}\text { Turkey (Izmir) } \\
\text { [27] }\end{array}$ & 3.1 & - & - & - & 7.4 & 7 & 186 \\
\hline $\begin{array}{l}\text { Turkey } \\
\text { (Giresun) [62] }\end{array}$ & 4.6 & 22 & 50.2 & 2379 & 17.7 & 36.1 & 713 \\
\hline $\begin{array}{l}\text { Turkey } \\
\text { (Çanakkale) }^{c}\end{array}$ & $\begin{array}{c}1.6-15.2 \\
(5.6)\end{array}$ & $\begin{array}{c}<0.5-3.9 \\
(1.4)\end{array}$ & $\begin{array}{c}2-21.7 \\
(8.1)\end{array}$ & $\begin{array}{l}<10-87 \\
(28.4)\end{array}$ & $\begin{array}{c}0.5-7.8 \\
(3.6)\end{array}$ & $\begin{array}{c}0.6-201.3 \\
(68.3)\end{array}$ & $\begin{array}{c}92.3-1025 \\
(260.7)\end{array}$ \\
\hline
\end{tabular}

According to Figure 3, the highest EF values (>200) were observed for As, $\mathrm{Zn}$ and $\mathrm{Cd}$ in both seasons. $\mathrm{Pb}, \mathrm{Mg}$, and $\mathrm{Cu}$ had $\mathrm{EF}$ values between $>10$ to $>100$, depending on the season. The lowest $\mathrm{EF}$ values were observed for $\mathrm{Ni}$ and $\mathrm{Cr}$, which were slightly higher than 1 . A study conducted in İstanbul, measuring fewer elements than this study showed that $\mathrm{Pb}, \mathrm{V}, \mathrm{Cu}, \mathrm{Ni}$, and $\mathrm{Co}$ had $\mathrm{EF}$ values $>100$, indicating the major contribution of anthropogenic sources such as industry and traffic [30]. In another study conducted in Singapore, the same elements that we observed in our study were predominant and attributed to the anthropogenic sources [66]. Relatively high contributions of urbanization and industrial activities have been shown the reasons of heavy metal pollution in rainwater of a region, that was close to petrochemical companies in Iran [22]. Even though the lowest heavy metal levels occurred in central Tibetan Plateau, which can be assumed as a remote environment with the least anthropogenic pollution source impact, long-range transport of the pollutants found to have contribution on heavy metal content in the rainwater of Tibet [64]. Like our outcomes, studies conducted in Beijing and İzmir, Turkey found $\mathrm{Zn}$ as the predominant heavy metal in the rainwater $[27,67]$. In another study conducted in Australia, 
elevated $\mathrm{Pb}$ and $\mathrm{Zn}$ levels that exceeded the limit values were observed in the rainwater [68]. $\mathrm{Zn}$ was shown to be a potential carcinogen and oral reference dose (RfD) was estimated as $0.3 \mathrm{mg} / \mathrm{kg}$-day [69]. On the other hand, no study had As enrichment in the rainwater as high as found in this study.

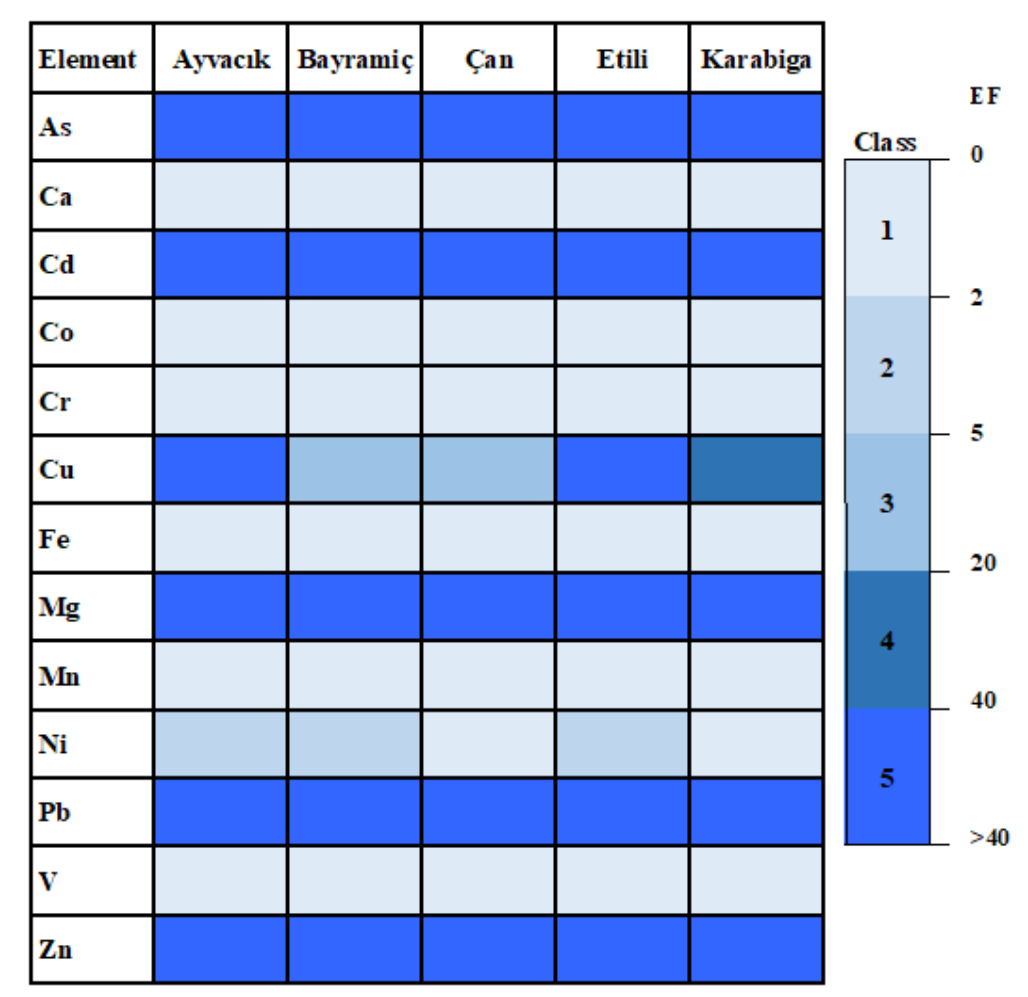

Figure 3. Heat map for enrichment factor $\left(\mathrm{EF}_{\text {rainwater }}\right)$ of the selected elements in rainwater over the study period at the study sites.

\section{Conclusions}

On Earth, atmosphere interact with crust and thus simultaneous monitoring of the environmental pollution in both parts of the environment is important. Soil and rainwater samples were taken in different parts of Çanakkale, Turkey, in two seasons along with the prevailing wind direction (from NE to SW), as wind has the potential to distribute pollutants emitted into the air throughout its path.

Physical parameters of rainwater $\mathrm{pH}(3.2-8)$ and EC values $(98-486 \mathrm{us} / \mathrm{cm})$ varied in a wide range, depending on the characteristics of the region and the meteorological parameters. Concentrations of the selected elements were measured by ICP-MS. All sampling locations in this study were far from the traffic sources. Unlike some studies conducted in urban sites, traffic was not considered as a major anthropogenic source in this study. Instead, mining activities and coal-fired power plants were major anthropogenic sources, in addition to potential contribution of natural rock characteristics of the soil on some of the heavy metals such as As. In addition to coal-fired power plants and open-pit mines available in the city, agricultural activity is the main socioeconomic activity at all of the sampling sites.

The highest enrichments were found for $\mathrm{Pb}$ in rainwater and $\mathrm{As}$ in soil samples. Elevated $\mathrm{As}$ levels found in the samples can pose a great risk for public health and agriculture. The study result showed that the elemental composition of the samples was influenced by the enhanced air plume dispersion of anthropogenic pollution sources along the prevailing wind directions over the city. The cumulative amount of the pollutants emitted into the air may show increasing trend from Karabiga to Ayvacik by enhanced air plume dispersion due to wind characteristics in the province. Also, As, $\mathrm{Zn}$, and Cd were enriched in the soil and air with high magnitude. Therefore, there is an urgent need to conduct more interdisciplinary studies covering more than one part of the environment. 


\section{Acknowledgements}

This work is supported by the Scientific Research Commission of Canakkale Onsekiz Mart University, (COMU BAP, FBA-2017-1317). Authors would like to thank Ayvacik, Çan and Biga Forest Management Chiefs and Ekrem Yusuf Uludag for their support in field works.

\section{ORCID}

Sibel Mentese: 0000-0002-0395-3603

Özlem Tonguc Yayintas: 0000-0002-3554-1881

Batuhan Bas: 0000-0002-7188-7484

Latife Ceyda İrkin: 0000-0001-6603-8413

Selehattin Yilmaz: 0000-0003-4607-3523

\section{References}

[1] S. Mentese and B. Bas (2020). A Year - round motoring of ambient volatile organic compounds across Dardanelles strait, J.Chem.Metrol.14, 177-189.

[2] S. Mentese, C. Bakar, N.A. Mirici, S. Cevizci and M.T. Otkun (2018). Associations between respiratory health and ambient air quality in Canakkale, Turkey: A long term cohort study, Environ. Sci. Pollut. Res. 25, 12915-12931.

[3] P.K. Lee, J.C. Touray, P. Baillif and J.P. Ildefonse (1997). Heavy metal contamination of settling particles in a retention pond along the A-71 motorway in Sologne, France, Sci. Total. Environ. 201, 1-15.

[4] P. Sands (2003). Principles of International Environmental Law, 2nd ed. London, Cambridge.

[5] A. Karatepe (2006). Chromosorb-105 reçinesi ve membran filtre kullanılarak bazı eser elementlerin zenginleştirilmesi ve türlemesi, Doktora Tezi. Erciyes Üniversitesi, Fen Bilimleri Enstitüsü, Kimya Anabilim Dalı. Kayseri.

[6] X. Li, C.S. Poon and P.S. Liu (2001). Heavy metal contamination of urban soils and street dusts in Hong Kong, Appl. Geochem. 16(11-12), 1361-1368.

[7] A. Baba, G. Gurdal and F. Sengunal (2008). Effects of leachant temperature and pH on leachability of metals from fly ash. A case study: Can thermal power plant, province of Canakkale, Turkey, Environ. Monit. Assess. 139, 287-298.

[8] S. Khan, Q. Cao, Y.M. Zheng, Y.Z. Huang and Y.G. Zhu (2008). Health risks of heavy metals in contaminated soils and food crops irrigated with wastewater in Beijing, China, Environ. Pollut. 152, 686692.

[9] A. Chlopecka, J.R. Bacon, M.J. Wilson and J. Kay (1996). Forms of cadmium, lead, and zinc in contaminated soils from southwest Poland, J. Environ. Qual. 25, 69-79.

[10] A. Karczewska (1996). Metal species distribution in top- and sub-soil in an area affected by copper smelter emissions, Appl. Geochemistry 11, 35-42.

[11] M. Kaasalainen and M. Yli-Halla (2003). Use of sequential extraction to assess metal partitioning in soils. Environ. Pollut. 126, 225-233.

[12] S. Mentese, N.A. Mirici, M.T. Otkun, E. Palaz, D. Tasdibi, S. Cevizci and O. Cotuker (2015). Association between respiratory health and indoor air pollution exposure in Canakkale, Turkey, Build. Environ. 93(1), $72-83$.

[13] S. Mentese, N.A. Mirici, T. Elbir, G.T. Tuygun, C. Bakar, M.T. Otkun and S. Oymak (2020). A Comprehensive assessment of ambient air quality in Çanakkale city: Emission inventory, air quality monitoring, source apportionment, and respiratory health indicators Atmos. Pollut. Res. 11, 2282-2296.

[14] Çanakkale Municipality (2018). Canakkale. https://www.canakkale.bel.tr/en/sayfa/icerik/2/0/1375 (accessed: May 21, 2018).

[15] F. Rueda-Holgado, M.R. Palomo-Marin, L. Calvo-Blazquez, F. Cereceda-Balic, E. Pinilla-Gil (2014). Fractionation of trace elements in total atmospheric deposition by filtrating-bulk passive sampling, Talanta 125, 125-130.

[16] R.D. Boone, D.F. Grigal, P. Sollins, R.J. Aherns and D.E. Armstrong (1999). Soil sampling, preparation, archiving and quality control. In: Robertson GP, Coleman DC, Bledsoc CS, Sollins P (ed.). Standard soil methods for long-term ecological research. Oxford University Press, New York pp. 3-28.

[17] C.A. Black (1965). Methods of Soil Analysis: Part I Physical and mineralogical properties, American Society of Agronomy, Madison, Wisconsin, USA. 
[18] S.A. Sinex, D.A. Wright (1988). Distribution of trace metals in the sediments and biota of Chesapake Bay, Mar. Pollut. Bull. 19, 425-431.

[19] M. Barbieri, G. Sappa, S. Vitale, B. Parisse and M. Battistel (2014). Soil control of trace metals concentrations in landfill: A case study of the largest landfill in Europe. Malagrotta, Rome, .J Geochem. Explor. 143, 146-154.

[20] K.H. Wedepohl (1995). The composition of the continental crust, Ingerson lecture, Geochim. Cosmochim . Acta 59(7), 1217-1232.

[21] A. Demirak, A. Balci, H. Karaoğlu and B. Tosmur (2006). Chemical characteristics of rain water at an urban site of south western Turkey, Environ. Monit. Assess. 123(1-3), 271-83.

[22] M.R. Mehr, B. Keshavarzi and A. Sorooshian (2019). Influence of natural and urban emissions on rainwater chemistry at a southwestern Iran coastal site, Sci. Total. Environ. 668, 1213-1221.

[23] G. Gulsoy, M. Tayanc and F. Erturk (1999). Chemical analyses of the major ions in the precipitation of Istanbul, Turkey, Environ. Pollut. 105(2), 273-280.

[24] B. Tuncer, B. Bayar, C. Yesilyurt and G. Tuncel (2001) Ionic composition of precipitation at the central Anatolia (Turkey), Atmos. Environ. 35, 5989-6002.

[25] C. Okay, B.O. Akkoyunlu and M. Tayanc (2002). Composition of wet deposition in Kaynarca, Turkey, Environ. Pollut. 118(3), 401-410.

[26] B.O. Akkoyunlu and M. Tayanc (2003). Analyses of wet and bulk deposition in four different regions of Istanbul, Turkey, Atmos. Environ. 37(25), 3571-3579.

[27] A. Muezzinoglu and S.C. Cizmecioglu (2006). Deposition of heavy metals in a Mediterranean climate area, Atmos. Res. 81(1), 1-16.

[28] M. Koçak, N. Mihalopoulos and N. Kubilay (2009). Origin and source regions of PM10 in the Eastern Mediterranean atmosphere, Atmos. Res. 92(4), 464-474.

[29] L. Saylan, H. Toros and O. Sen (2009). Back trajectory analysis of precipitation chemistry in the urban and forest areas of Istanbul, Turkey, Clean-Soil Air Water 37(2), 132-135.

[30] N. Uygur, F. Karaca and O. Alagha (2010). Prediction of sources of metal pollution in rainwater in Istanbul, Turkey using factor analysis and long-range transport models, Atmos. Res. 95, 55-64.

[31] Turkish Standardization Institute (2014). Tap water standard (TS 266).

[32] O. Deniz, A. Baba and G. Tarcan (2014). Çan (Çanakkale) Havzasındaki soğuk yeraltı sularının hidrojeolojik ve hidrojeokimyasal özellikleri, 67. Geological Congress of Turkey, April 14-18, 2014, Proceedings book, p.338. (in Turkish).

[33] O. Deniz, A. Baba and N.A. Erdin (2014). Investigation of the source of arsenic in groundwater around the Ayvacık district (Canakkale-Turkey), Geophysic. Res. Abst. 16, EGU2914-15913-1.

[34] O. Deniz and A. Calik (2015). Su-kayaç ilişsisinin Sarıçay (Çanakkale) havzası doğu kesimindeki yeraltı suyu kalitesine etkisi, 68th Geology Congress of Turkey, 06-10 April 2015, Proceedings book, p.172 (in Turkish).

[35] O. Deniz and A. Calik (2015). Sarıçay (Çanakkale) havzasında ayrışmış kayaçlardan çıkan su kaynaklarının içme suyu standartları bakımında değerlendirilmesi, UCTEA Chamber of Geological Engineeris 2nd Medical Geology Symposium, 12-15th November 2015, Konya, Proceedings book, p.69 (in Turkish).

[36] J.W. Bates (2008). Bryophyte Biology. In: Goffinet B, Shaw AJ (ed) 2nd edn. Cambridge University Press

[37] H.J.M. Bowen (1979). Environmental Chemistry of the Elements, Academic Press, NY.

[38] Ministry of Environment and Urbanization (2010). Regulation on soil pollution control and polluted areas by point sources, Official Journal Issue No: 27605 and date: June 8, 2010.

[39] General Directorate of Mineral Research and Exploration (MTA) (2019a), http://www.mta.gov.tr/v3.0/sayfalar/hizmetler/maden-haritalari/canakkale.pdf (accessed: May 2, 2019).

[40] M.N. Khan, A.A. Wasim, A. Sarwar and M.F. Rasheed (2011). Assessment of heavy metal toxicants in the roadside soil along the N-5, National Highway, Pakistan, Environ. Monit. Assess 182(1-4), 587-595.

[41] O. Morton-Bermea, E.H. Álvarez, I. Gaso, N. Segovia (2002). Heavy metal concentrations in surface soils from Mexico Cit, Bull. Environ. Contam. Toxicol. 68(3), 383-388.

[42] M. Wawer, T. Magiera, G. Ojha, E. Appel, G. Kusza, S. Hu and N. Basavaiah (2015). Traffic-related pollutants in roadside soils of different countries in Europe and Asia, Water Air Soil Pollut. 226(7), 216.doi: 10.1007/s11270-015-2483-6

[43] A. Mandal and D. Sengupta (2006). An assessment of soil contamination due to heavy metals around a coal-fired thermal power plant in India, Environ. Geol. 51(3), 409-420.

[44] U. Bilge and K.M. Çimrin (2013). Viranşehir-Kızıltepe karayolu kenarındaki topraklarda motorlu taşıtlardan kaynaklanan ağır metal kirliliği. Tarım Bilimi Derg. 19, 323-329.

[45] A. Özkan (2017). Antakya-Cilvegözü karayolu etrafindaki tarım arazilerinde ve bitkilerdeki ağır metal kirliliği, Çukurova Üniv. Müh.-Mimar. Fak. Derg. 32(3), 9-18. 
[46] S.O. Fakayode and B.I. Olu-Owolabi (2003). Heavy metal contamination of roadside topsoil in Osogbo, Nigeria: its relationship to traffic density and proximity to highways, Environ. Geol. 44(2), 150-157.

[47] H. Zhang, Z. Wang and Y. Zhang, Z. Hu (2012). The effects of the Qinghai-Tibet railway on heavy metals enrichment in soils, Sci. Total. Environ. 439, 240-248.

[48] J. Aslam, S.A. Khan and S.H. Khan (2013). Heavy metals contamination in roadside soil near different traffic signals in Dubai, United Arab Emirates, J. Saudi Chem. Soc. 17(3), 315-319.

[49] M. Imperato, P. Adamo, D. Naimo, M. Arienzo, D. Stanzione and P. Violante (2003). Spatial distribution of heavy metals in urban soils of Naples city (Italy), Environ. Pollut. 124(2), 247-256.

[50] C.T. Keleş (2007). Konya şehir merkezi yol ve parklarında ağır metal kirliliği, Doctoral dissertation, Selçuk University, Konya.

[51] R.A. Sutherland, C.A. Tolosa, F.M.G. Tack and M.G. Verloo (2000). Characterization of selected element concentrations and enrichment ratios in background and anthropogenically impacted roadside areas, Arch. Environ. Contam. Toxixol. 38, 428-438.

[52] H. Yongming, D. Peixuan, C. Junji and E.S. Posmentier (2006). Multivariate analysis of heavy metal contamination in urban dusts of Xi'an, Cent, China, Sci. Total. Environ. 355, 176-186.

[53] A. Baba, H. Ozcan and O. Deniz (2005). Environmental impact by spill of geothermal fluids at the geothermal field of Tuzla, Canakkale-Turkey, Proceedings of World Geothermal Congress, Antalya, Turkey, 24-29 April 2005, p.1-8.

[54] A. Baba, G. Gurdal and F. Sengunalp (2010). Leaching characteristics of fly ash from fluidized bed combustion thermal power plant: Case study: Çan (Çanakkale-Turkey), Fuel Process Technol. 91, 10731080 .

[55] A. Karaca, C. Türkmen, S. Arcak, K. Haktanır, B. Topçuoğlu and H. Yıldız (2005). Çayırhan termik santralı emisyonlarının yöre topraklarının bazı agir metal ve kükürt kapsamlarına etkilerinin belirlenmesi, Ankara Üniv. Çevre Bilim. Derg. 1(1), 17-25.

[56] A. Apaydın (2005). Investigation of soil pollution originated from industries: Samsun-Tekkeköy region, Master Dissertation, Hacettepe University, Ankara.

[57] G. Yaylal1-Abanuz (2011). Heavy metal contamination of surface soil around Gebze industrial area, Turkey, Microchem. J. 99, 82-92.

[58] T.M. Galal and H.S. Shehata (2015). Bioaccumulation and translocation of heavy metals by Plantago major L. grown in contaminated soils under the effect of traffic pollution, Ecol. Indicat. 48, 244-251.

[59] O.A. Al-Khashman (2005). Study of chemical composition in wet atmospheric precipitation in Eshidiya area, Jordan, Atmos. Environ. 39(33), 6175-6183.

[60] G.P. Hu and R. Balasubramanian (2003). Wet deposition of trace metals in Singapore, Water Air Soil Pollut. 144, 285-300.

[61] V.A. Chudaeva, O.V. Chudaev and S.G. Yurchenko (2008). Chemical composition of precipitation in the southern part of the Russian Far East, Water Resour. 35(1), 58-70.

[62] A. Kara and A. Türkmen (2015). Giresun sahil yolundan alınan yağmur suyu örneklerindeki ağır metal kirliliği, Black Sea J. Sci. 5(12), 9-27.

[63] M. Koulousaris, M. Aloupi and M.O. Angelidis (2009). Total metal concentrations in atmospheric precipitation from the Northern Aegean Sea, Water Air Soil Pollut. 201(1-4), 389.

[64] Z. Cong, S. Kang, Y. Zhang and X. Li (2010). Atmospheric wet deposition of trace elements to central Tibetan Plateau, Appl. Geochem. 25(9), 1415-1421.

[65] O. Connan, D. Maro, D. Hébert, P. Roupsard, R. Goujon, B. Letellier and S. Le Cavelier (2013). Wet and dry deposition of particles associated metals $(\mathrm{Cd}, \mathrm{Pb}, \mathrm{Zn}, \mathrm{Ni}, \mathrm{Hg})$ in a rural wetland site, Marais Vernier, France, Atmos. Environ. 67, 394-403.

[66] A. Báez, R. Belmont, R. García, H. Padilla and M.D.C. Torres (2007). Chemical composition of rainwater collected at a southwest site of Mexico City, Mexico, Atmos. Res. 86(1), 61-75.

[67] W. Ouyang, B. Guo, G. Cai, Q. Li, S. Han, B. Liu and X. Liu (2015). The washing effect of precipitation on particulate matter and the pollution dynamics of rainwater in downtown Beijing, Sci. Total. Environ. $\mathbf{5 0 5}, 306-314$.

[68] R. Huston (2009). Characterisation of atmospheric deposition as a source of contaminants in urban rainwater tanks, Water Res. 43, 1630-1640.

[69] United States Environmental Protection Agency (US EPA), Integrated Risk Information System (IRIS), Zinc and compounds; CASRN 7440-66-6, Available online: http://cfpub.epa.gov/ncea/iris/irisdocuments/documents/subst-/0426_summary.pdf (accessed: 23 April, 2019).

[70] S. Melaku, V. Morris, D. Raghavan and C. Hosten (2008). Seasonal variation of heavy metals in ambient air and precipitation at a single site in Washington, DC. Environ. Pollut. 155(1), 88-98.

[71] A.P.G. Fontenele, A. Fornaro and J.J. Pedrotti (2009). Measurements of heavy metals in dry and wet deposition in São Paulo City, In Highway and Urban Environment (pp. 105-113). Springer, Dordrecht. 
[72] K. Deboudt, P. Flament and M.L. Bertho (2004). Cd, Cu, Pb and $\mathrm{Zn}$ concentrations in atmospheric wet deposition at a coastal station in Western Europe, Water Air Soil Pollut. 151(1-4), 335-359.

[73] E.A. Kanellopoulou (2001). Determination of heavy metals in wet deposition of Athens, The Int. J. Global NEST 3(1), 45-50.

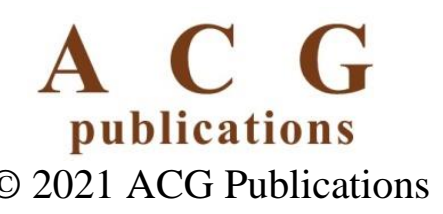

